\title{
Optimalisasi Tugas dan Fungsi Pembimbing Kemasyarakatan Dalam Upaya Pencegahan Overcrowded di Lembaga Pemasyarakatan
}

\author{
Ricky Fahriza ${ }^{1}$ \\ ${ }^{1}$ Politeknik Ilmu Pemasyarakatan, Kemenkumham Republik Indonesia \\ Corresponding author. Email: ricky.fahriza@ gmail.com \\ Naskah diterima: 02-04-2020; revisi: 07-12-2020; disetujui: 17-12-2020 \\ DOI: https://doi.org/10.46257/jrh.v24i2.102
}

\begin{abstract}
Abstrak
Overcrowded merupakan masalah utama yang menjadi penghambat keberhasilan tujuan pemasyarakatan. Pemasyarakatan mengalami situasi krisis dimana Lembaga Pemasyarakatan mengalami kepadatan penghuni Lapas, Setiap tahunnya overcrowded terjadi hampir di setiap Lembaga Pemasyarakatan selalu meningkat. Rumusan masalah yaitu bagaimana optimalisasi tugas dan fungsi Pembimbing Kemasyarakatan dalam melakukan upaya pencegahan overcrowded. Tujuan penelitian yaitu untuk menganalisis optimalisasi tugas dan fungsi pembimbing kemasyarakatan dalam upaya preventif atau pencegahan overcrowded yang terjadi di lembaga pemasyarakatan. Kegunaan penelitian yaitu dapat memberikan manfaat dalam upaya pencegahan overcrowded di Lembaga Pemasyarakatan. Metode penelitian menggunakan yuridis normative. Hasil penelitian pembimbing kemasyarakatan harus melakukan upaya preventif / pencegahan terjadinya potensi lebih tinggi overcrowded melalui peran, tugas, dan fungsinya yang sudah diamanatkan dalam undang-undang. Salah satu upaya yang dapat dilakukan adalah pengoptimalan peran Pembimbing Pemasyarakatan dengan cara optimalisasi proses integrasi warga binaan pemasyarakatan, sehingga dapat mencegah overcrowded di Lembaga Pemasyarakatan. Kesimpulan yaitu tugas dan fungsi pembimbing kemasyarakatan dapat dioptimalkan dan mampu menjadi upaya pencegahan overcrowded di Lapas maupun Rutan.
\end{abstract}

Kata kunci: optimalisasi tugas dan fungsi, pembimbing kemasyarakatan, pencegahan, overcrowded.

\section{Optimalization Tasks and Functions of Correctional Advisor in Overcrowded Prevent Effort in Correctional Institution}

\begin{abstract}
Overcrowded is a major problem that becomes a sure obstacle to correctional goals. The correctional facility is experiencing a crisis where the Penitentiary has a density of prisoners. Every year there is an overcrowded in almost every penitentiary. The formulation of the problem is how to optimize the duties and functions of the Community Guidance in preventing overcrowded prevention. The purpose of this research is to analyze the duties and functions of the social adviser in an effort to prevent or prevent overcrowded occurrences in correctional institutions. The usefulness of research can provide benefits in
\end{abstract}




\begin{abstract}
preventing overcrowded in correctional institutions. The research method uses normative juridical. The results of the research of community supervisors must take preventive measures/prevention of higher potential overcrowded through their roles, duties and functions that have been mandated by law. One of the efforts that can be done is to optimize the role of Correctional Advisors by optimizing the integration process of prison assisted citizens, to prevent overcrowding in prisons. The conclusion is that the duties and functions of community counsellors can be optimized and can prevent overcrowded prevention in prisons or detention centres.
\end{abstract}

Keywords: optimalization of tasks and functions, correctional advisor, prevention, overcrowded.

\title{
I. Pendahuluan
}

Peningkatan jumlah narapidana di Lapas maupun tahanan di Rutan meningkat sangat tajam. Criminal Justice System atau sistem peradilan pidana di Indonesia pun menjadi salah satu penentu dalam kondisi tersebut. Komponenkomponen kelembagaan yang menjadi implementasi dalam sistem yaitu:

a. Kepolisian yang mempunyai kewenangan dalam hal penyelidikan, dan penyidikan, penangkapan.

b. Kejaksaan yang mempunyai kewenangan dalam hal penuntutan.

c. Pengadilan dengan kewenangan pemeriksaan dalam persidangan.

d. Advokat mempunyai kewenangan dalam hal pembelaan terhadap terdakwa maupun tersangka.

e. Pemasyarakatan sebagai pelaksana putusan/penetapan hakim/pengadilan.

Pemberian hukuman di penjara memang menjadi salah satu bentuk pelaksanaan pidana. Tempat pelaksanaan hukuman penjara telah berubah istilah menjadi Lembaga Pemasyarakatan. Hakim yang lebih dominan untuk menjatuhkan hukuman pidana penjara ternyata berdampak sangat signifikan terhadap peningkatan jumlah narapidana di Lembaga Pemasyarakatan. Hal inilah yang menjadi tantangan permasalahan bagi Direktorat Jendral Pemasyarakatan sebagai Instansi yang berwenang mengelola Lembaga Pemasyarakatan serta dalam pemecahan permasalahan overcrowded di Lapas/Rutan. 
Perkembangan pemidanaan di Indonesia telah mengalami beberapa perubahan. Pertama sebagai alat Retribution/Restrain (pengekangan penggudangan) yang dalam operasionalisasinya mempergunakan tekanan rendah pada masyarakat dan tekanan rendah pada individu. Artinya kurang memperhatikan kepentingan individu dan kurang memperhatikan kepentingan masyarakat. Kedua, Penjara sebagai alat Deterence atau penjeraan, menggunakan model tekanan tinggi pada masyarakat dan tekanan rendah pada individu dengan menggunakan cara penjeraan. Artinya, kepentingan masyarakat sangat diutamakan daripada kepentingan individu. Ketiga, Penjara sebagai alat Rehabilitation menggunakan model tekanan rendah pada masyarakat dan tekanan tinggi pada individu. Artinya fokus perhatian lebih ditujukan kepada individu pelanggar, Sedangkan masyarakat kurang diikutsertakan dalam proses perbaikan. Keempat, Penjara sebagai alat Re-integration yaitu pemulihan hubungan dengan masyarakat, menggunakan model tekanan tinggi pada masyarakat dan tekanan tinggi pada individu pelanggar. Artinya fokus perhatian sama tinggi, baik terhadap masyarakat maupun terhadap individu pelanggaran. Perkembangan pada paradigma reintegrasi ini mulai menaruh kepercayaan kepada masyarakat agar masyarakat ikut serta dalam memperlakukan dan mengintegrasikan Narapidana ke dalam masyarakat. Konsep masyarakat pembina ini dipandang akan lebih efisien dan efektif dari sistem liberalis individualis. Paradigma ini juga berarti menempatkan masyarakat untuk turut serta memikirkan dan membina narapidana atas dasar anggapan bahwa masyarakat adalah tempat di mana masalah-masalah bersumber. (Hasanudin Massaile, 2015: 49). Namun pada kenyataannya kondisi pada mayoritas Lembaga Pemasyarakatan mengalami overcrowded dan berdampak kepada proses reintegrasi kepada warga binaan Pemasyarakatan, sehingga perlu adanya upaya optimal diberikan hak integrasi serta tindakan pencegahan. Disinilah tantangan bagi Pemasyarakatan harus melaksanakan sistem dengan baik sesuai dengan Undang-Undang Nomor 12 Tahun 1995 tentang Pemasyarakatan yang menjelaskan bahwa sistem Pemasyarakatan melaksanakan pembinaan secara terpadu antara Pembina dan yang dibina (narapidana), maka pembinaan harus 
dilaksanakan secara maksimal supaya pulih hidup, kehidupan, dan penghidupan narapidana setelah keluar dari lembaga pemasyarakatan. Salah satu yang dapat menghambat optimalnya pembinaan adalah overcrowded. Berdasarkan uraian di atas maka tulisan ini memfokus pada upaya-upaya yang dilakukan dalam mencegah terjadinya overcrowded di Lembaga Pemasyarakatan melalui optimalisasi tugas dan fungsi pembimbing kemasyarakatan pemasyarakatan.

Dari latar belakang di atas, maka penulis mengambil perumusan masalah, yakni: Bagaimana optimalisasi tugas dan fungsi Pembimbing Kemasyarakatan dalam upaya pencegahan overcrowded/kepadatan penghuni di Lembaga Pemasyarakatan?

Adapun Tujuan penelitian ini adalah untuk mengetahui bagaimana optimalisasi tugas dan fungsi pembimbing kemasyarakatan dalam upaya preventif atau pencegahan overcrowded yang terjadi di lembaga pemasyarakatan. Serta dapat berguna untuk memberikan solusi yang dapat dipertimbangkan terhadap instansi terkait. Metode Penelitian ini bersifat yuridis empiris dan menggunakan pendekatan kualitatif yang didukung data yang bersifat kuantitatif. Pendekatan kualitatif dilaksanakan dengan pengumpulan dan memanfaatkan semua informasi terkait pokok permasalahan, dan beberapa data bersifat kuantitatif yang mendukung namun secara terbatas berupa angka yang terkait dengan permasalahan penelitian.

Penelitian ini bersifat yuridis empiris yang bertujuan untuk mengetahui pelaksanaan optimalisasi tugas dan fungsi pembimbing kemasyarakatan dalam upaya preventif atau pencegahan overcrowded di lembaga pemasyarakatan. Data dalam penelitian ini adalah data sekunder yang dikumpulkan berdasarkan penelusuran literatur, peraturan perundang-undangan, dan data yang bersumber dari berbagai sumber

\section{Pembahasan}

Pada dasarnya hukum tidak pernah terlepas dari kehidupan manusia dalam hidup bermasyarakat. Tanpa adanya hukum, akan menimbulkan ketidakselarasan antara kehidupan masyarakat dengan norma-norma 
kemanusiaan. Hukum menjadi suatu pedoman penting yang mengatur norma hidup manusia yang berperan penting dalam mencapai tujuan ketentraman kehidupan masyarakat. Barda Nawawi Arief menjelaskan bahwa tujuan dari suatu kebijakan pemidanaan yaitu untuk menetapkan suatu pidana yang berkaitan erat dengan tujuan politik kriminal dan melindungi masyarakat dengan tujuan untuk mencapai kesejahteraan. Oleh karena itu, penting untuk mengetahui tujuan maupun fungsi pemidanaan, maka tidak terlepas dari teoriteori tentang pemidanaan yang ada. Teori-teori pemidanaan berhubungan langsung dengan hukum pidana dalam arti subjektif. Yang berarti suatu hak atau kewenangan negara untuk menjatuhkan dan menjalankan pidana kepada orang yang terbukti telah melanggar hukum pidana. Setelah abad 19, muncul teoriteori pembaharuan mengenai tujuan pemidanaan. Tiga teori pembaharuan mengenai pemidanaan, yakni Teori Pembalasan (Absolut), Teori Tujuan (Relatif), Teori Gabungan. (Putri Hikmawati, 2016: 76)

Pelaksanaan pemidanaan telah berkembang dan berubah secara konsep dalam perkembangan sistem pemasyarakatan, maka saat ini Indonesia ini telah menerapkan Teori Gabungan. Prof. Van Hamel menjelaskan bahwa dalam teori gabungan, pemidanaan bertujuan untuk melindungi masyarakat dengan menciptakan keterbiban guna memberantas kejahatan sebagai suatu gejala masyarakat. Pemidanaan tidak lagi menggunakan sistem kepenjaraan yang tidak sesuai dengan sistem pemasyarakatan yang berlandaskan Pancasila dan UndangUndang Dasar Negara Republik Indonesia 1945. Dalam konsepsi Pemasyarakatan, pemidanaan bukan dimaksudkan sebagai upaya balas dendam, namun sebagai upaya pembinaan bagi pelaku kejahatan, sekaligus menjadi tindakan pencegahan terhadap terjadinya kejahatan. Undang-Undang nomor 12 Tahun 1995 menjelaskan bahwa Pemasyarakatan adalah suatu tatanan mengenai arah dan batas serta cara pembinaan warga binaan pemasyarakatan berdasarkan Pancasila yang dilaksanakan secara terpadu antara Pembina, yang dibina, dan masyarakat untuk meningkatkan kualitas warga binaan pemasyarakatan agar menyadari kesalahan, memperbaiki diri, dan tidak mengulangi tindak pidana sehingga dapat diterima kembali oleh lingkungan masyarakat, dapat aktif 
berperan dalam pembangunan,dan dapat hidup secara wajar sebagai warga yang baik dan bertanggung jawab.

Pemasyarakatan sebagai tempat berlangsungnya proses pembinaan dan pembimbingan bagi setiap warga binaan pemasyarakatan agar dapat kembali dan diterima oleh masyarakat (reintegrasi sosial). Namun, adanya keterbatasan pelaksanaan, dan semakin meningkatnya jumlah tahanan dan narapidana menyebabkan pembinaan sistem pemasayarakatan berjalan kurang optimal. Serta kebijakan hukum pidana dalam peningkatkan penjatuhan sanksi pidana oleh pengadilan yang terkesan over kriminalisasi. Hal ini menekankan penjatuhan pidana penjara sebagai konsekuensi penjatuhan sanksi pidana dalam bentuk perampasan kemerdekaan. Dalam lampiran Permenkumham No 11 tahun 2017 tentang Grand Design Penanganan Overcrowded pada Rumah Tahanan Negara dan Lembaga Pemasyarakatan secara jelas dinyatakan bahwa overcrowded salah satunya disebabkan karena Regulasi Pemidanaan terhadap pelaku tindak pidana belum mengalami pembaharuan. Pentingnya upaya pembaharuan regulasi yang lebih bertumpu pada ultimum remedium dalam sistem peradilan pidana sehingga tercapai pembaharuan hukum dalam mewujudkan kesejahteraan masyarakat dan perlindungan terhadap masyarakat dapat terwujud (Rully, et al., 2018:47). Faktor yang menyebabkan over kriminalisasi yaitu kewenangan penyidik yang semakin banyak untuk bisa menahan perbuatan, sehingga yang diatur akan semakin banyak dan bisa dihukum kalau dilakukan atau tidak dilakukan. Kemudian, apa dan siapa yang dihukum seringkali tidak proporsional penjatuhan hukumannya. Seperti contoh karena adanya over punishment, penjatuhan hukuman yang tidak proporsional kepada pengguna narkoba, dimana seharusnya para pengguna narkoba lebih baik direhabilitasi daripada harus divonis hukuman penjara. Kedua hal ini dirasakan berdampak sangat signifikan dalam meningkatnya jumlah warga binaan sehingga menimbulkan permasalahan baru di dalam lembaga pemasyarakatan, yaitu overcrowded. Untuk mengatasi permasalahan tersebut, maka Pemasyarakatan harus memiliki strategi dalam menangani maupun mencegah overcrowded yaitu dengan Optimalisasi tugas dan fungsi pembimbing 
kemasyarakatan. Menurut Kamus Besar Bahasa Indonesia, berasal dari kata optimal yang berarti optimalisasi mempunyai arti tertinggi, paling menguntungkan. Optimalisasi merupakan tindakan pengoptimalan suatu proses, menjadikan terbaik atau metodologi untuk membuat sesuatu sistem menjadi lebih efektif atau sempurna secara fungsional. Dengan adanya pengoptimalan tugas dan fungsi pembimbing kemasyarakatan akan menekan angka overcrowded di lembaga pemasyarakatan.

\section{A. Overcrowded}

Overcrowded adalah situasi krisis dimana Lembaga Pemasyarakatan mengalami kepadatan penghuni Lapas. Situasi overcrowded ini mengakibatkan beberapa permasalahan yaitu pertama, kurang berjalan dengan baik program pembinaan seperti pembinaan kerja, keterampilan, rehabilitasi sosial dan medis. Kedua, meningkatnya pelarian diri dikarenakan banyaknya penghuni lapas dan rutan, hal ini berarti terjadi perbandingan yang tidak ideal antara jumlah penghuni dengan petugas pengamanan. Ketiga, terbatasnya sarana dan prasarana yang menunjang berjalannya pembinaan seperti makanan, tempat tidur, air bersih sehingga dapat menimbulkan resiko konflik antar narapidana. Keempat, timbulnya potensi gangguan kamtib. Seperti peredaran narkoba, kerusuhan dll.

Tabel 1. Peningkatan Jumlah Tahanan dan Narapidana di Rutan dan Lapas

\begin{tabular}{|c|c|c|c|c|c|c|}
\hline No & Tahun & Tahanan & $\begin{array}{c}\text { Nara- } \\
\text { pidana }\end{array}$ & $\begin{array}{c}\text { Jumlah total } \\
\text { Penghuni }\end{array}$ & $\begin{array}{c}\text { Kapasitas Hunian } \\
\text { Rutan dan Lapas }\end{array}$ & $\begin{array}{c}\text { Selisih jumlah Penghuni } \\
\text { dan Kapasitas hunian }\end{array}$ \\
\hline 1 & 2015 & 57.547 & 119.207 & 176.754 & 131.931 & 44.823 \\
\hline 2 & 2016 & 65.554 & 138.997 & 204.551 & 119.797 & 84.757 \\
\hline 3 & 2017 & 70.739 & 161.342 & 232.081 & 123.481 & 108.600 \\
\hline 4 & 2018 & 72.106 & 183.274 & 255.380 & 131.931 & 123.449 \\
\hline 5 & 2019 & 64.005 & 201.643 & 265.648 & 131.931 & 133.717 \\
\hline 6 & 2020 & 65.037 & 208.667 & 273.704 & 131.931 & 141.773 \\
\hline
\end{tabular}

Sumber : Sistem Database Pemasyarakatan (http://smslap.ditjenpas.go.id/public/grl/current/ monthly), diakses 21 Maret 2020.

Data di atas menunjukkan lonjakan angka yang signifikan setiap tahunnya yang berarti Lembaga Pemasyarakatan dalam situasi kritis dikarenakan 
mengalami kepadatan penghuni. Pemasyarakatan telah berupaya untuk membangun Lapas dan Rutan baru guna mengatasi overcrowded, namun dirasakan belum ada perubahan yang mampu menjawab tantangan permasalahan tersebut. Sehingga dengan adanya Pembimbing Kemasyarakatan diharapkan mampu untuk mencegah overcrowded dengan upaya optimalisasi tugas dan fungsi Pembimbimbing Kemasyarakatan yaitu dalam bentuk percepatan program integrasi di Lapas sesuai dengan kebijakan Crash Program.

\section{B. Tugas dan Fungsi Pembimbing Kemasyarakatan}

Undang-Undang Nomor 12 Tahun 1995 tentang Pemasyarakatan menjelaskan Balai Pemasyarakatan atau selanjutnya disebut BAPAS merupakan suatu pranata untuk melaksanakan pembimbingan terhadap Klien Pemasyarakatan. Pembimbing kemasyarakatan dapat dikatakan sebagai penghubung dalam transisi warga binaan kembali ke masyarakat setelah selesai menjalani hukuman pidananya. Pembimbing Kemasyarakatan secara tidak langsung memiliki tanggung jawab untuk menunjang keberhasilan dari pelaksanaan fungsi Balai pemasyarakatan. Fungsi dari Balai Pemasyarakatan yaitu:

1. Penelitian kemasyarakatan yang digunakan sebagai rekomendasi dalam sidang peradilan.

2. Registrasi terhadap klien pemasyarakatan.

3. Mengikuti sidang peradilan di PN (Pengadilan Negeri) dan mengikuti sidang Tim Pengamat Pemasyarakatan di Lapas

4. Memberikan bimbingan kejutan kepada klien pemasyarakatan, bekas narapidana dan Anak negara

5. Melakukan pekerjaan/urusan yang berkaitan dengan tata usaha Pemasyarakatan. (Albert Supriadi, 2016: 28)

Berdasarkan uraian diatas, maka pembimbing kemasyarakatan memiliki peran yang strategis dalam melaksanakan tugas dan fungsinya secara optimal dan dapat mencegah pelonjakan angka overcrowded. Anak yang berhadapan dengan hukum akan mendapatkan pendampingan, dan apabila dapat diupayakan 
diversi maka akan mencegah anak masuk ke dalam Lembaga Pemasyarakatan Khusus Anak (LPKA), dan untuk Narapidana dewasa yang mendapatkan hak integrasi dengan baik akan kembali ke masyarakat dan mengurangi angka overcrowded di Lembaga Pemasyarakatan. Dalam pemberian hak integrasi maupun pelaksanaan diversi pada perkara anak selalu tidak terlepas dari peran pembimbing kemasyarakatan, sehingga perlu dilaksanakan tugas dan fungsi pembimbing kemasyarakatan secara optimal untuk mencegah maupun mengurangi overcrowded di Lapas maupun Rutan.

\section{Peran Balai Pemasyarakatan dalam Community Based Corrections}

Community Based Correction adalah jenis program pembinaan yang diberikan kepada narapidana dalam menjalani sisa pidananya. Narapidana diberikan kesempatan untuk kembali ke tengah-tengah masyarakat dengan pengawasan atau supervisi tertentu (Hamja, 2015:14). Secara terbatas, Sistem Pemasyarakatan telah mempraktekkan community-based correction, dalam istilah Pemasyarakatan dikenal dengan pembebasan bersyarat (parole) dan asimilasi yang sesuai dengan kerangka CBC dan kewenangannya dari sistem pemasyarakatan. Balai Pemasyarakatan memiliki peran yang sangat penting dalam perkembangan hukum di Indonesia khususnya dalam upaya perlindungan anak dan untuk pelaksanaan pembinaan berbasis masyarakat. Sistem Pemasyarakatan memiliki peran penting dalam mendorong $\mathrm{CBC}$, dari tahap pra adjudikasi, adjudikasi, hingga post adjudikasi. Peran tersebut dimiliki oleh Balai Pemasyarakatan dan dilaksanakan oleh pembimbing kemasyarakatan.

Pada tahap pra ajudikasi Balai Pemasyarakatan melaksanakan fungsi pendampingan dan membuat penelitian kemasyarakatan guna mengetahui latar belakang sosial serta alasan dilakukannya tindak pidana. Laporan penelitian kemasyarakatan akan dijadikan rekomendasi oleh Hakim dalam proses ajudikasi. Pada tahap post adjudikasi peran yang dimiliki Balai Pemasyarakatan sangat penting dalam bentuk pembinaan berbasis masyarakat seperti asimilasi, pembebasan bersyarat, dan cuti (program integrasi). Sebelum narapidana menjalani asimilasi atau telah bekerja pada pihak ketiga, harus ada penelitian kemasyarakatan yang dilakukan oleh pembimbing kemasyarakatan. Disinilah 
peran dari pembimbing kemasyarakatan untuk melaksanakan tugas dan fungsinya secara optimal sehingga dengan adanya pembinaan berbasis masyarakat akan membuat overcrowded di lapas maupun rutan dapat berkurang.

Pembimbing kemasyarakatan dalam melaksanakan tugasnya memiliki tanggung jawab dan dasar pikiran bahwa narapidana bukanlah orang yang jahat, selain mereka mendapatkan perlindungan hukum, narapidana dapat mengembangkan potensi-potensi yang ada di dalam diri mereka. Hal inilah yang akan menjadi penentu keberhasilan dari tugas dan fungsi pembimbing kemasyarakatan dalam melaksanakan tugasnya.

\section{Penanganan Overcrowded melalui Proses Reintegrasi Sosial.}

Reintegrasi sosial adalah suatu proses menyiapkan warga binaan pemasyarakatan agar dapat memperbaiki diri sehingga dapat kembali dan diterima dalam kehidupan bermasyarakat. Reintegrasi sosial dianggap merupakan kebijakan alternatif yang efektif dalam mengatasi overcrowded di Lapas dan Rutan. Proses integrasi akan mendorong percepatan pengeluaran warga binaan pemasyarakatan dari dalam Lapas/Rutan. Proses reintegrasi sosial tersebut dapat diberikan sebelum masa hukuman habis, melalui pemberian hak kepada warga binaan pemasyarakatan untuk memperoleh kesempatan menjalani hukuman di luar Lapas.

Program pembinaan untuk mengintegrasikan Narapidana ke dalam kehidupan masyarakat setelah memenuhi persyaratan yang telah ditentukan, yaitu: Pembebasan Bersyarat (PB) adalah bebasnya narapidana setelah menjalani sekurang-kurangnya dua pertiga masa pidana nya dengan ketentuan 2/3 tersebut tidak kurang dari 9 bulan. Persyaratan ditetapkan oleh Peraturan Menteri Hukum dan Hak Asasi Manusia Nomor 3 Tahun 2018 tentang Syarat dan Tata Cara Pemberian Remisi, Asimilasi, Cuti Mengunjungi Keluarga, Pembebasan Bersyarat, Cuti Menjelang Bebas dan Cuti Bersyarat. Syarat tersebut seperti berkelakuan baik selama menjalani masa pidana paling singkat 9 bulan terakhir dihitung sebelum tanggal 23 masa pidana dan telah mengikuti program pembinaan dengan baik, serta masyarakat dapat menerima program kegiatan pembinaan narapidana. Cuti Menjelang Bebas (CMB) sebagaimana 
Pasal 1 Ayat (3) yaitu proses pembinaan narapidana dan anak pidana di luar Lembaga Pemasyarakatan setelah menjalani dua pertiga masa pidana sekurangkurangnya 9 bulan berkelakuan baik dan Cuti Bersyarat (CB) adalah Pembinaan untuk mengintegrasikan narapidana dan anak didik Pemasyarakatan ke dalam kehidupan masyarakat setelah memenuhi persyaratan yang telah ditentukan. Narapidana juga mendapatkan asimilasi menurut Permenkumham Nomor 21 Tahun 2016 Pasal 1 Ayat (4) yaitu proses pembinaan Narapidana yang dilaksanakan dengan membaurkan Narapidana dalam kehidupan masyarakat. Program asimilasi dilaksanakan di Lembaga Pemasyarakatan Terbuka. Lapas terbuka berbeda dengan lapas pada umumnya, Lapas terbuka hanya menjalankan sebagian kewenangan, tugas, dan tanggung jawab dari lapas umum. Lapas terbuka lebih mengedepankan pembinaan Community Based Correction, atau pembinaan yang melibatkan masyarakat dengan lebih mengedepankan pendekatan secara kekeluargaan dan dengan pengamanan minimum (minimum security) serta tanpa adanya jeruji besi seperti tertutup (Haryono, 2018: 9). Pembentukan Lapas terbuka secara khusus bertujuan untuk memulihkan kesatuan hubungan hidup kehidupan dan penghidupan narapidana di tengah masyarakat dan memberikan kesempatan bagi narapidana untuk menjalankan fungsi sosial secara wajar dan untuk meningkatkan peran aktif petugas maupun masyarakat serta narapidana itu sendiri dalam pelaksanaan pembinaan Lapas terbuka memberikan program pembinaan dengan membuka kesempatan yang seluas-luasnya bagi narapidana untuk meningkatkan keterampilan serta kemampuan guna mempersiapkan diri untuk hidup secara mandiri di tengah masyarakat. Ketentuan yang diberikan terhadap narapidana dan anak didik Pemasyarakatan yang melaksanakan asimilasi, diberikan pembinaan dan pembimbingan yaitu:

a. Untuk latihan keterampilan, pendidikan serta pembinaan di luar Lapas dan dilakukan oleh petugas Lembaga Pemasyarakatan.

b. Untuk kegiatan yang dilaksanakan dalam kerjasama pihak ketiga, kerja mandiri, dan penempatan di lembaga pemasyarakatan terbuka yang 
dilaksanakan oleh petugas Lembaga Pemasyarakatan atau Balai Pemasyarakatan.

Sedangkan Cuti Mengunjungi Keluarga (CMK) adalah proses pembinaan bagi narapidana dan anak didik pemasyarakatan yang dilaksanakan melalui kunjungan narapidana ke keluarga asalnya. CMK dapat dilaksanakan setiap tiga bulan bagi narapidana yang memiliki masa pidana 12 bulan. Salah satu tujuan dari CMK adalah untuk mencegah penolakan masyarakat dan menghilangkan stigma terhadap narapidana.

Peraturan Menteri Hukum dan HAM Nomor 03 Tahun 2018 Tentang Syarat dan Tata Cara Pemberian Remisi, Asimilasi, Cuti Mengunjungi Keluarga, Pembebasan Bersyarat, Cuti Menjelang Bebas, dan Cuti Bersyarat. Menjelaskan bahwa peran Pembimbing kemasyarakatan memiliki peran dalam pemenuhan syarat tersebut untuk menentukan tingkat keberhasilan proses reintegrasi sosial melalui litmas yang dilaksanakan oleh Pembimbing kemasyarakatan. Salah satu syarat untuk mendapatkan hak reintegrasi sosial adalah melalui litmas yang dibuat pembimbing kemasyarakatan. Penelitian kemasyarakatan berdasarkan tahapannya dalam pembinaan dan masa hukuman warga binaan Pemasyarakatan yaitu jika hukuman yg dijalani belum mencapai 1/3 maka penelitian kemasyarakatan digunakan dalam menentukan program pembinaan awal terhadap warga binaan pemasyarakatan. Jika telah menjalani 1/2 hukumannya maka penelitian kemasyarakatan digunakan dalam pengajuan pembebasan bersyarat. Klien yang menjalani program integrasi seperti pembebasan bersyarat akan menjadi klien Balai Pemasyarakatan dan melaksanakan wajib lapor serta pembimbingan oleh pembimbing kemasyarakatan. Disinilah peran seorang pembimbing kemasyarakatan dalam memberikan pemulihan bagi klien yang telah kembali di tengah kehidupan bermasyarakat. Dengan adanya pembimbingan yang baik maka akan mencegah klien kembali melakukan tindak pidana atau disebut residivise.

Pembimbing kemasyarakatan juga melaksanakan tugas dan fungsinya dalam litmas penempatan awal maupun pembinaan awal. Sesuai dengan surat edaran Jenderal Pemasyarakatan Nomor PAS:176-PK 01.04.03 Tahun 2019 
tentang Penilaian Perubahan Perilaku dan Pemenuhan Kebutuhan Bagi Klien, menjelaskan bahwa dengan keterampilan pembimbing kemasyarakatan dalam merekomendasikan penempatan awal maupun penilaian perubahan perilaku serta pemenuhan kebutuhan akan menempatkan narapidana di lembaga pemasyarakatan sesuai dengan kebutuhan. Maka dengan program ini akan berdampak menekan rendah tingkat overcrowded di lembaga pemasyarakatan. Berdasarkan Peraturan Menteri Hukum dan Hak Asasi Manusia Nomor 35 Tahun 2018 tentang Revitalisasi penyelenggaraan Pemasyarakatan menjelaskan bahwa penempatan narapidana sesuai dengan tingkat resiko yaitu :

a. Lembaga Pemasyarakatan Super Maximum security menjalankan program pembinaan bagi narapidana tingkat resiko tinggi untuk mendorong perubahan perilaku dan penurunan tingkat resiko. Resiko tersebut meliputi membahayakan keamanan negara; dan membahayakan keselamatan masyarakat

b. Lembaga Pemasyarakatan maximum security menjalankan program pembinaan narapidana untuk mendorong perubahan sikap dan perilaku narapidana yang sadar akan kesalahan, patuh terhadap hukum dan tata tertib serta peningkatan disiplin.

c. Lembaga Pemasyarakatan medium security menjalankan program pembinaan narapidana untuk mendorong perubahan sikap dan perilaku yang sadar akan kesalahan, patuh terhadap hukum dan tata tertib serta meningkatkan kompetensi dan kemampuan diri narapidana.

d. Lembaga Pemasyarakatan minimum security menjalankan program pembinaan narapidana untuk membentuk perubahan sikap dan perilaku, meningkatkan kemandirian dan produktivitas narapidana.

Pembimbing kemasyarakatan harus memiliki kompetensi untuk melaksanakan assessment resiko residivis, resiko terjadinya tindak pidana baru atau disebut kriminogen, dan screening untuk kategori penempatan pembinaan bagi narapidana berdasarkan kebutuhan. Dengan penempatan narapidana sesuai tingkatnya akan meningkatkan keberhasilan program pembinaan, serta program integrasi sehingga dapat mencegah resiko overcrowded.

\section{E. Kebijakan Crash Program}

Menteri hukum dan hak asasi manusia menginstruksikan untuk pembenahan pelayanan Pemasyarakatan salah satunya percepatan pembebasan 
bersyarat, cuti bersyarat, cuti menjelang bebas, remisi online, penanganan overcrowded. Maka untuk merespon instruksi Menteri Hukum dan hak asasi manusia, Ibnu Khuldun mewakili Dirjen Pemasyarakatan dalam membuka seminar nasional IPKEMINDO (organisasi profesi ikatan pembimbing kemasyarakatan Indonesia) pada tanggal 12 Desember 2019 di Jakarta menyampaikan bahwa kebijakan crash program yaitu sebuah inovasi yang akan menyederhanakan penelitian kemasyarakatan sehingga akan menunjang kinerja pembimbing kemasyarakatan dan asisten pembimbing kemasyarakatan. Penyederhanaan secara administrasi ini yang dimaksud adalah isi dokumen penelitian kemasyarakatan yang sekarang hanya termuat 2 lembar dan ketersediaan pembimbing kemasyarakatan untuk menjadi penjamin dengan syarat apabila klien tidak memiliki penjamin dari keluarga. Dengan kebijakan crash program diharapkan permasalahan overcrowded dapat teratasi dengan baik. Dalam kebijakan ini pembimbing kemasyarakatan sebagai penjamin narapidana dan anak yang tidak memiliki penjamin. Sehingga hak hak narapidana dapat dipenuhi dalam pengajuan pembebasan bersyarat, cuti bersyarat, dan cuti menjelang bebas. Dengan adanya percepatan ini akan mempersingkat waktu serta memudahkan warga binaan Pemasyarakatan untuk memperoleh hak-haknya.

Dalam kebijakan ini ditekankan pula strategi dalam peningkatan profesionalisme dan kompetensi pembimbing kemasyarakatan dalam rangka mendukung percepatan revitalisasi penyelenggaraan Pemasyarakatan. Pelaksanaan crash program memiliki target yang ingin dicapai untuk mengatasi overcrowded di sebagian besar Lapas dan Rutan di seluruh Indonesia. Meskipun pada realisasinya beberapa target belum terpenuhi atau belum tercapai dengan baik. Dirjen Pemasyarakatan menjelaskan bahwa target realisasi program pemasyarakatan dan pencapaian di tahun 2019 terkait pemberian hak integrasi dan hak remisi yaitu:

Tabel 2. Tabel target dan pencapaian Crash Program

\begin{tabular}{|c|c|c|c|c|}
\hline No & Jenis Program Integrasi & Target & Orang Capaian & Keterangan \\
\hline 1 & Remisi umum & 99.027 & 130.383 & Tercapai \\
\hline 2 & Remisi khusus & 82.200 & 114.561 & Tercapai \\
\hline 3 & Pembebasan Bersyarat & 32.409 & 40.131 & Tercapai \\
\hline
\end{tabular}




\begin{tabular}{|l|c|c|c|c|}
\hline 4 & Cuti bersyarat & 9.826 & 29.909 & Tercapai \\
\hline 5 & Asimilasi & 11.490 & 5.236 & Belum Tercapai \\
\hline 6 & Cuti Menjelang Bebas & 1.306 & 966 & Belum Tercapai \\
\hline
\end{tabular}

Sumber : Deklarasi Resolusi Pemasyarakatan Tahun 2020 [Paul M Nuh, (https://kbr.id/kabar _bisnis/012020/_advertorial_menkumham_deklarasikan_resolusi_pemasyarakatan_tahun_202 0/101992.html), diakses 21 Maret 2020]

Berdasarkan data diatas, dapat dilihat bahwa dengan adanya program ini dapat mengurangi angka overcrowded di Lembaga Pemasyarakatan. Peran pembimbing kemasyarakatan menjadi salah satu penentu keberhasilan pelaksanaan crash program. Peran balai pemasyarakatan serta tugas dan fungsi pembimbing kemasyarakatan dalam melaksanakan penelitian kemasyarakatan menjadi tolok ukur bagi pemberian hak integrasi tersebut kepada narapidana

\section{F. Kelompok Masyarakat Peduli Pemasyarakatan (POKMAS)}

Menuju reintegrasi yang sehat serta untuk meningkatkan pembinaan dan peran masyarakat dalam restorative Justice maka melalui Balai Pemasyarakatan dibentuklah kelompok masyarakat peduli Pemasyarakatan sebagai mitra kerja maupun wadah pemberdayaan masyarakat. Yang dimaksud dengan kelompok ini adalah kumpulan mitra kerja Pemasyarakatan yang memiliki kepedulian tinggi dan bersedia untuk turut berpartisipasi dalam penyelenggaraan Pemasyarakatan. Dengan adanya pokmas ini akan meningkatkan partisipasi dari masyarakat. Tujuan disusunnya pembentukan kelompok masyarakat peduli Pemasyarakatan yaitu:

1. Membentuk warga binaan Pemasyarakatan menjadi manusia seutuhnya menyadari kesalahan memperbaiki diri dan tidak mengulan gi tindak pidana sehingga dapat diterima oleh lingkungan masyarakat dapat aktif berperan dalam pembangunan dan dapat hidup secara wajar sebagai warga yang baik dan bertanggung jawab.

2. Optimalisasi pemberdayaan atau keterlibatan masyarakat dalam penyelenggaraan Pemasyarakatan.

3. Mewujudkan kesamaan persepsi dan pemahaman dalam pembentukan kelompok masyarakat peduli Pemasyarakatan. 
(Surat Keputusan Direktur Jenderal Pemasyarakatan nomor: PAS06.OT.02.02 Tahun 2020 tentang Pedoman Pembentukan Kelompok Masyarakat Peduli Pemasyarakatan)

Upaya ini akan menekan angka residivis dan membentuk pilar-pilar dukungan dari masyarakat melalui pemerintahan, yayasan, lembaga, badan hukum maupun perseorangan. Adanya kelompok masyarakat peduli Pemasyarakatan ini diharapkan bermanfaat bagi pihak-pihak yang terkait serta meningkatkan peranan organisasi maupun pemerintah dalam mewujudkan pelanggaran hukum yang mandiri baik secara finansial maupun sosial sehingga pelanggar hukum akan pulih kembali menjadi anggota masyarakat yang berguna dan turut menciptakan situasi yang nyaman dan aman bagi masyarakat. Adapun sasaran yang akan dikerjakan bersama kelompok masyarakat meliputi program pembinaan yang pertama di bidang kemandirian yaitu berupa penyaluran tenaga kerja dan wirausaha maupun bentuk lain yang disesuaikan dengan kebutuhan. Yang kedua, dalam bidang kepribadian meliputi kegiatan peningkatan keimanan, intelektual klien, keagamaan, psikolog dan lain-lain. Yang ketiga, sasaran di bidang hukum dengan tujuan meningkatkan kesadaran hukum serta peningkatan layanan dalam memberi kepastian hukum, seperti penyuluhan dan bantuan hukum. Yang keempat, di bidang kemasyarakatan yaitu meliputi bidang sosial dengan keterlibatan klien pada lingkungan masyarakat dengan aktivitas sosial, meliputi organisasi kemasyarakatan, masyarakat di sekitar klien maupun lembaga swadaya masyarakat. Pelaksanaan pokmas harus didukung oleh setiap anggota dan elemen-elemen yang bersangkutan berdasarkan nilai aktif yang berarti semua pihak yang terkait harus mampu berkreasi dan beraksi membentuk kegiatan yang bersifat universal guna mendukung pelaksanaan sesuai bidang masing-masing. Dalam pelaksanaan pokmas tidak lepas dari pemberian pelatihan kerja yang dianggap sangat penting untuk mencapai tujuan keberhasilan kelompok masyarakat. Tujuan dari pelatihan adalah:

1. Untuk mendapatkan ilmu pengetahuan (knowledge) yang cukup supaya dapat melaksanakan tugasnya dengan baik. 
2. Mendapatkan kemampuan yang memadahi (skill) untuk diterapkan dalam pekerjaan.

3. Untuk membentuk sikap (attitude) yang baik serta memiliki kesadaran atas pekerjaannya. Setelah mendapatkan pelatihan, klien akan merubah sikap ke arah yang lebih baik dalam sosial maupun finansial, yang mengarah kepada upaya preventif klien melakukan kesalahan atau melanggar hukum.

Pihak-pihak yang memenuhi syarat menjadi pokmas yaitu dapat bersifat individu, akademisi, organisasi kemasyarakatan, organisasi yang bergerak di bidang wirausaha atau bisnis, dan organisasi yang berbasis masyarakat. Bentuk kerjasama pun harus sesuai dengan kebutuhan klien Pemasyarakatan, dan dipertimbangkan sesuai pemenuhan kebutuhan pekerjaan seperti akses terkait lowongan pekerjaan, penyaluran tenaga kerja sesuai dengan keterampilan, bantuan modal usaha, penyediaan instruktur dalam pelatihan keterampilan, dan dukungan infrastruktur produksi. Dalam kerjasama juga tidak luput dari pemenuhan kesehatan seperti akses kesehatan yang tersedia dengan baik, mendapatkan pengobatan yang tidak berbiaya, dan fasilitas rehabilitasi bagi penyalahgunaan narkoba. Selain kebutuhan kesehatan pelaksanaan juga mempertimbangkan kebutuhan mental spiritual seperti tenaga psikolog, penyuluhan agama, dan sarana untuk beribadah guna memenuhi pemberian hakhak spiritual.

Kelompok masyarakat yang memenuhi syarat untuk menjadi pokmas memiliki kriteria:

1. Peduli terhadap Pemasyarakatan

2. Mampu dan bersedia dalam kerjasama yang selanjutnya akan menjadi mitra kerja Pemasyarakatan.

3. Memiliki dan mampu Memegang teguh komitmen serta mampu bertanggung jawab dalam pelaksanaan kesepakatan kerjasama.

4. Memiliki cukup sumber daya yang bermanfaat.

Dengan adanya pokmas, klien akan mampu untuk kembali pulih dalam kehidupan sosialnya maupun secara finansial, sehingga tidak melakukan 
perbuatan yang melanggar hukum. Mengingat dari beberapa kasus yang berujung kepada pemberian pidana penjara berawal dari kurangnya pemenuhan finansial para pelanggar hukum. Maka langkah ini dianggap tepat untuk mencegah terjadinya residivis bagi narapidana maupun klien Pemasyarakatan. Penetapan kelompok masyarakat peduli pemasyarakatan tsb terbentuk melalui Surat Keputusan Kepala Balai Pemasyarakatan. Beberapa Balai Pemasyarakatan di Indonesia telah melaksanakan kerjasama yang baik dengan pokmas sehingga klien Pemasyarakatan dapat menyalurkan keterampilan sesuai dengan minat dan bakat, dan untuk menjadi manusia yang lebih mandiri dan jauh dari tindak pidana. Tentu hal ini akan menekan angka residivis di lembaga pemasyarakatan karena menjadi upaya pencegahan narapidana melakukan residivis sehingga masuk kembali ke dalam lembaga pemasyarakatan yang berdampak kepada overcrowded di lembaga pemasyarakatan

\section{Penutup}

\section{A. Kesimpulan}

Dengan kondisi overcrowded yang terjadi di Lapas, pemasyarakatan memiliki tujuan untuk memulihkan kembali hidup, kehidupan, dan penghidupan narapidana. Narapidana memiliki hak integrasi dan harus diberikan dengan optimal dan mampu kembali hidup di tengah masyarakat. Namun disisi lain, hak integrasi dan kebijakan yang berkaitan dengan pemberian integrasi ternyata mampu memberikan solusi dalam mengatasi overcrowded.

Tugas dan fungsi pembimbing kemasyarakatan dapat dioptimalkan dan mampu menjadi upaya pencegahan overcrowded di Lapas maupun Rutan. Kebijakan crash program dalam percepatan pemberian hak integrasi akan membuat optimal tugas pembimbing kemasyarakatan untuk pemenuhan hak integrasi narapidana. Pembimbing kemasyarakatan juga memiliki peran dalam pelaksanaan Community Based Correctional pada tahap pra hingga Post adjudikasi. Masyarakat juga dapat berperan dalam pulihnya kehidupan klien pemasyarakatan. Hadirnya Pokmas (kelompok masyarakat peduli pemasayarakatan) juga memberikan ruang bagi masyarakat luas untuk lebih 
aktif, sehingga dg kembalinya narapidana di tengah kehidupan bermasyarakat mampu mengurangi angka overcrowded di Lapas dan Rutan di Indonesia

\section{B. Saran}

Adapun saran dalam penelitian ini adalah:

1. Seluruh elemen penegak hukum sebaiknya saling berkoordinasi dalam rangka mengurangi overkriminalisasi terhadap pelanggar hukum sehingga overcrowded di lembaga pemasayarakatan dapat dicegah.

2. Penyuluhan tentang pentingnya peran masyarakat dalam rangka pemulihan narapidana dan klien perlu dilakukan oleh Balai Pemasyarakatan. Sehingga masyarakat luas akan turut memahami konsep "Pokmas" dan lebih aktif berpartisipasi dalam mewujudkan tujuan pemasyarakatan.

\section{Daftar Pustaka}

Departemen Pendidikan Nasional. Kamus Besar Bahasa Indonesia. Jakarta: Balai Pustaka, 2005.

Massaile, Hasanuddin. Refleksi 50 Tahun Sistem Pemasyarakatan: Anatomi Permasalahan dan Upaya Mengatasinya. Jakarta: Center for Detention Studies, 2015.

Novian, Rully dan Supriyadi Widodo Eddyono, Ajeng Gandini Kamilah, dkk. Strategi Menangani Overcrowding di Indonesia: Penyebab, Dampak dan Penyelesaiannya. Jakarta: Institute for Criminal Justice Reform (ICJR), 2018.

Hamja. "Model Pembinaan Narapidana Berbasis Masyarakat (Community Based Corrections) Dalam Sistem Peradilan Pidana”. Jurnal Mimbar Hukum. Vol 27, No 3, Oktober 2015.

Haryono. "Optimalisasi Pelaksanaan Tugas Dan Fungsi Lapas Terbuka Dalam Proses Asimilasi Narapidana." Jurnal Ilmiah Kebijakan Hukum, Balitbangham. Vol. 12, No. 3, Oktober 2018.

Hambali, Azwad Rachmat. "Penerapan Diversi terhadap Anak yang Berhadapan dengan Hukum dalam Sistem Peradilan Pidana”. Jurnal Ilmiah Kebijakan Hukum, Balitbangham Vol 13, No 1, Maret 2019. 
Hikmawati, Puteri. "Pidana Pengawasan Sebagai Pengganti Pidana Bersyarat Menuju Keadilan Restoratif”. Jurnal Negara Hukum. Vol.7, No.1, Juni 2016.

A, Supriadi. Program Pembimbingan bagi Warga Binaan Pemasyarakatan yang Memperoleh Pembebasan Bersyarat. Skripsi. Universitas Negeri Islam Syarif Hidayatullah. Jakarta. 2016.

Republik Indonesia. Undang-Undang Nomor 12 Tahun 1995 Tentang Pemasyarakatan. Lembaran Negara Tahun 1995 No. 77. Tambahan Lembaran Negara Nomor 3614. , Peraturan Menteri Hukum dan Hak Asasi Manusia No. 21 Tahun 2016 tentang Perubahan Atas Peraturan Menteri Hukum dan Hak Asasi Manusia Nomor 21 Tahun 2013 tentang Syarat dan Tata Cara Pemberian Remisi, Asimilasi, Cuti Mengunjungi Keluarga, Pembebasan Bersyarat, Cuti Menjelang Bebas, dan Cuti Bersyarat. 2016. , Peraturan Menteri Hukum dan Hak Asasi Manusia nomor 35 tahun 2018 tentang Revitalisasi Penyelenggaraan Pemasyarakatan. 2018. , Surat Keputusan Direktur Jenderal Pemasyarakatan Nomor: PAS-06.OT.02.02 Tahun 2020 tentang Pedoman Pembentukan Kelompok Masyarakat Peduli Pemasyarakatan.

Bamsur, "IPKEMINDO Dorong Crash Program Pembebasan 34.000 Narapidana Hingga Maret 2020" (http://www.kabartoday.co.id/ipkemindo-dorongcrash-program-pembebasan-34-000-narapidana-hingga-maret), diakses pada 20 April 2020

KBR. "Menkumham Deklarasikan Resolusi Pemasyarakatan Tahun 2020" (https://kbr.id/kabar_bisnis/012020/_advertorial_menkumham_deklarasi kan_resolusi_pemasyarakatan_tahun_2020/101992.html), diakses pada 22 Maret 2020.

Sistem Database Pemasyarakatan. "Sistem Database Pemasyarakatan" (http://smslap.ditjenpas.go.id/public/grl/current/monthly), diakses pada 21 Maret 2020. 